Н. Б. Гонтаренко. - Ростов н/Д : Феникс, 2007. - 155 с. 6. Дудка-Побережна Я. I. Унікальність співочого таланту видатного оперного майстра сцени ХХ століття Бориса Гмирі / Я. І. Дудка-Побережна // Педагогічна майстерність як система професійномистецьких компетентностей. - Вип 3.- Чернівці, 2011.- С.605-608. 7. Ламетри Ж. О. Сочинения / Ж. О. Ламетри ; [пер. с фр.]. - Москва : Мысль, 1983. - 509 с. 8. Марков Б. В. Философская антропология / Б. В. Марков. - СПб. : Лань, 1997. - 384 с. 9. Ортега-иГассет Х. Что такое философия? / Х. Ортега-и-Гассет// Ортега-и-Гассет Х. Что такое философия? - Москва : Наука, 1991. - С. 3-191. 10. Падалка Г. М. Педагогіка мистецтва (теорія і методика викладання мистецьких дисциплін) : [монографія] / Г. М. Падалка. - Київ : Освіта України, 2008. - 274 с. 11. Пеньковский А. Б. Радость и удовольствие в представлении русского языка / А. Б. Пеньковский // Логический анализ языка. Культурные концепты. - Москва : Наука, 1991. - С. 1-55. 12. Сі Даофен. Значення народно-пісенної творчості у виконавському мистецтві Китаю / Ci Даофен// Вісник ЛНУ імені Тараса Шевченка, 2013. - № 10 (269). - Ч. I, - С. 111-115. 13. Цзо Чжэнь-гуань. О музыкальнотеоретической системе «люй» в китайской музыке / Цзо Чжэнь-гуань // Музыка народов Азии и Африки. - Вып. 4. - Москва : Сов. композитор, 1987. - С. 257-272 14. Философский энциклопедический словарь ; [гл. редакция: Л. Ф. Ильичев, П. Н. Федосеев, С. М. Ковалев, В. Г. Панов]. - Москва : Советская энциклопедия, 1983. - 840 с. 15. Фромм Э. Психоанализ и этика / Э. Фромм ; [пер. с нем.]. - Москва : ООО «Из-ва АСТ ЛТД», 1998. - 568 с.

УДК 378. 1

Дмитро Ткач

\title{
СИСТЕМНІСТЬ НАРИСНОЇ ГЕОМЕТРІЇ ЯК КОНЦЕПТУАЛЬНА ОСНОВА ЇЇ ФУНДАМЕНТАЛЬНОСТІ
}

Ткач Д. І. Системність нарисної геометрії як концептуальна основа іiї фундаментальності.

Стаття присвячується доведенню фундаментальності навчальної дисципліни «Нарисна геометрія», яка викладається у всіх технічних і творчих ВНЗ як загальноосвітня. Це доведення грунтується на діалектичної єдності нарисної геометрії, яка вважається прикладною наукою, і фундаментальної евклідової геометрії, яку нарисна «зображує» або графічно моделює.

Ключові слова: геометрія, графіка, система, структура, дидактика, оборотні зображення, педагогічна технологія.

Ткач Д. И. Системность начертательной геометрии как основа её фундаментальности.

Статья посвящается доказательству фундаментальности учебной дисциплины «Начертательная геометрия», которая преподаётся во всех технических и творческих вузах как общеобразовательная. Это доказательство основывается на диалектическом единстве начертательной геометрии, которая считается прикладной наукой, и фундаментальной евклидовой геометрии, которую начертательная «изображает» или графически моделирует.

Ключевые слова: геометрия, графика, система, структура, дидактика, обратимые изображения, педагогические технологии.

Tkach D. I. Systemacity of descriptive geometry as the basis of its fundamental nature. 
The article is devoted to the proof of the fundamental nature of the discipline «Descriptive Geometry», which is taught in all technical and creative universities as a general subject. This proof is based on the dialectical unity of descriptive geometry, which is considered as an applied science and fundamental Euclidean geometry, which is descriptive geometry «represents» or models graphically.

Key words: geometry, graphics, system, structure, didactics, reversible images, educational technology.

Якщо уявити, що рівень сучасного розвитку цивілізації на планеті Земля визначається рівнем якості матеріального оточення людини як продукту його інтелектуальної діяльності, то опосередковано можна судити про рівень геометрографічної освіченості його творців. Яскравими представниками змісту цього оточення є об'єкти будівництва і техніки - будинки і споруди, машини і механізми. Ці об'єкти принципово відрізняються один від одного за формою, змістом і призначенням, але початком, який їх об'єднує є їх штучна складеність 3 окремих елементів, які інтегруються в єдине ціле завдяки свідомому встановленню взаємозв'язків і відношень між ними. Іншими словами, все, що створене розумом і руками людини, є складними штучними системами взаємопов'язаних, а потому взаємодіючих елементів.

Такими ж, але природними системами, є об'єкти, процеси і явища навколишньої природи, які досліджуються природничими фундаментальними науками, що вивчають предмет свого дослідження як невідому систему задля розуміння особливостей його будови, устрою, конструкції або структури, тобто його елементів і характеру зв'язків між ними.

Однією з найголовніших природничих наук, яка описує навколишній світ, є евклідова геометрія як наука про розташування, розміри і форми його об'єктів. Евклід став першою людиною, який написав першу системну геометрію реального простору в його локальних масштабах, адекватно змоделювавши його структуру, яка складається 3 елементів - точок, ліній i площин як геометричних понять, що взаємно поєднуються зв'язками та відношеннями, які описані в 5 групах аксіом його геометрії, тобто вербальних тверджень, що не потребують доведень.

Евклідів простір як геометрична система є локалізованим у геометрично освіченої людини в концептуальному просторі знань його свідомості, створюючи в ньому своєрідний «конструктор» для мисленнєвої побудови уявних думко-образів неіснуючих об'єктів, які виступають як «натура» для їх зображення. Цю освіту людині надає середня школа, де вона вивчає евклідову геометрію протягом 5 років, але далеко не всі першокурсники, зокрема архітектурних факультетів, володіють зачатками професійної здібності до формування цих думко-образів як геометричних моделей неіснуючих у реальному просторі об'єктів.

Необов'язковість викладання в середній школі навчального предмета «Креслення» $\mathrm{i}$ відсутність ЗНО із креслення для абітурієнтів-архітекторів практично унеможливлюють розпочинати навчальний процес 3 нарисної геометрії на першому курсі 3 програмного матеріалу вищої школи. Окрім їх слабкої геометричної підготовки, часом спостерігається дуже низький рівень культури графічного виконання зображень нескладних уявних об'єктів, що в сукупності зумовлює тривалу кризу геометрографічної освіченості випускників середніх шкіл. Ця обставина створює велику психолого-педагогічну проблему подолання «порогу нерозуміння» матеріалу першого навчального предмета - нарисної геометрії, яка має статус загальнонавчальної, а не фундаментальної дисципліни, що є парадоксальним. Адже вона не має загальноприйнятого визначення і предмета дослідження, а як геометрія - 
не має власної аксіоматики. Ця обставина визначила її загальний кризовий стан, «виходом» 3 якого стало ï перейменування на прикладну геометрію, науковий розвиток якої також не сприяє подоланню зазначеної кризи геометрографічної освіченості шкільної i студентської молоді.

Одним із напрямів іï подолання пропонується звертання до першоджерела педагогічної науки - «Великої дидактики» Яна Амоса Коменського [1], який наголошував: «усе повинне виводитись із непорушних начал речей», тобто 3 пізнання властивостей природних утворень. Власне так творив свої «Начала» великий Евклід, який абстрактно описав їх геометричні властивості, без розуміння яких неможливе створення штучних об’єктів. Це розуміння покладено в основу переконливих знань, концептуальний зміст яких кодується точками і лініями на аркуші паперу у процесі їх графічного моделювання. У такий спосіб процес створення штучних систем є процесом їх геометрографічного моделювання, розуміння інтегральності якого повинно стати основою такої педагогічної технології, використання якої сприятиме подоланню вищеозначеної кризи. Актуальність обгрунтування і створення цієї технології є незаперечною.

Серед публікацій, присвячених останнім дослідженням в галузі теорії і методики викладання зображальних дисциплін в технічних і творчих ВНЗ, визначаються науковопедагогічні праці докторів педагогічних наук О. Джеджули, А. Гедзика, Г. Райковської, М. Козяра, М. Юсупової, В. Сидоренка, Д. Тхоржевського та ін.

У докторській дисертації О. Джеджула «Теорія і методика графічної підготовки студентів інженерних спеціальностей вищих навчальних закладів»[2] метою визначає «теоретичне обгрунтування та розробку педагогічної системи графічної підготовки студентів інженерних спеціальностей...», зазначаючи, що «особливістю графічної підготовки студентів є врахування тісного взаємозв'язку графічної діяльності з професійною діяльністю фахівця та специфіки оперування графічними формами інформації» [2, с. 6]. Тобто мовиться про «графічну» підготовку фахівця 3 метою надбання ним умінь оперування графічними формами інформації.., але про що? Мабуть, про уявлення предмета своє професійної діяльності. Але таке уявлення, як система знань про його елементи і характер зв'язків між ними, має суто геометричний зміст. Однак про нього в цій роботі не йдеться.

Докторська дисертація А. Гедзика «Система підготовки майбутнього вчителя технологій до викладання курсу креслення в загальноосвітніх навчальних закладах» [3] присвячена розробленню i науковому обгрунтуванню теоретичних i методичних основ професійно-графічної підготовки вчителів креслення, у яких його геометричному складнику відводиться роль засобу, який сприяє формуванню просторових уявлень як основи одержання «графічних знань». Однак з цим важко погодитися тому, що знання про об'єкт як систему, об'єктивні і геометричні, локалізовані в концептуальному просторі свідомості людини, яка спроможна їх «зобразити» завдяки набутим у процесі навчання умінням i навичкам зображальної чи графічної діяльності, що мають переважно суб'єктивний зміст. Зрозуміло, що рівень якості результатів такої діяльності однозначно залежить від повноти розуміння системної природи зображуваного об'єкта і рівня виконавчої майстерності автора його зображення.

Дослідження докторів педагогічних наук М. Козяра, Г. Райковської, М. Юсупової, В. Сидоренка, Д. Тхоржевського також спрямовані на обгрунтування теоретичних i методичних підвалин графічної діяльності без акцентування важливості його геометричного складника і забезпечення проектних зображень найважливішою властивістю оборотності. 3 цим важко погодитися. 
Мета статmі. На основі системності нарисної геометрії як теорії оборотних зображень, зокрема для навчання майбутніх архітекторів, довести нагальну необхідність офіційного надання їй статусу фундаментальної, а не прикладної науки тому, що вона $є$ геометрією картинного простору, аксіоматика якої графічно моделює аксіоматику фундаментальної геометрії евклідового простору і заснована на природовідповідній парадигмі системного розуміння як об'єкта, що підлягає зображенню, так і його оборотного зображення.

Відомо, що зображальна діяльність людини створює найбільш сприятливі умови спілкування між людьми тому, що зображальна мова є своєрідним «есперанто», зрозумілим кожному освіченому користувачу зображень. Адже будь-яке зображення - це інтелектуальний продукт його автора, який містить інформацію про властивості того, що зображене. Якщо автор - архітектор, то він створює оборотні зображення майбутніх об'єктів будівництва, які містять однозначну інформацію про позиційні і метричні властивості його майбутньої дійсної форми. Цієї інформації достатньо виконробу для здійснення будівництва об'єкта, яке абстрактно уявляється як процес установлення механічних зв'язків між його матеріальними елементами, характер яких графічно змодельований на робочих кресленнях архітектурного проекту. Цілком зрозуміло, що характер i конструктивно-композиційні властивості цих зв'язків визначають якість об'єкта, а його метричні або кількісні характеристики визначають його техніко-економічні показники. Ці обставини актуалізують необхідність вироблення майбутніми архітекторами впевненого розуміння об'єкта, що проектується, як системи взаємопов'язаних елементів, яке у їх свідомості формує його певний думко-образ як результат геометричного моделювання реальної структури майбутнього об'єкта. Адже свідомість оперує геометричними поняттями про елементи евклідового простору, - точки, лінії і площини, які вона поєднує зв'язками і відношеннями взаємної належності, порядку слідування, перетину, перпендикулярності, паралельності, дотику, конгруентності, подібності, гомотетичності, гомологічності, симетричності тощо. Іншими словами, якщо в концептуальному просторі знань майбутнього архітектора має місце своєрідний розумовий «конструктор» як набір певних понять про елементи і можливі зв'язки між ними, то він набуває спроможність варіативного конструювання в думках просторових уявлень про неіснуючі, але такі об'єкти, які підлягають створенню в реальному просторі.

Наведені міркування налаштовують свідомість на принциповий перегляд дидактичного змісту офіційного курсу нарисної геометрії як прикладної науки [4; 5], яка має інформаційно-пояснювальний характер без коректних визначень головних понять, тверджень і їх доведень, структурного аналізу вихідних умов, зокрема позиційних задач і їх алгоритмічного розв'язання тощо, тобто без явних ознак геометричної науки.

Такий перегляд органічно виникає під впливом незаперечності думки Я. А. Коменського про природовідповідність, формальну логічність і синтетичність тієї системи знань, яку педагогіка надає учнівській молоді. Якщо йдеться про геометрію взагалі, то вона $\epsilon$ наукою, яка синтетично описує певний простір через відповідний опис геометричних властивостей тих однорідних елементів, які його заповнюють. У зв'язку з цим нарисна геометрія є геометрією картинного простору, елементами якого є оборотні проекційні зображення як графічні моделі геометричних уявлень їх авторів про структуру зображених об'єктів, що аксіоматично описує ті їх зображальні властивості, які кодують інформацію про позиційні і метричні властивості їх дійсної форми. Але такі уявлення $\epsilon$ незаперечно системними, завдяки чому вони стають цілісними й інформаційно визначеними. 
Принцип системного розуміння природи будь-яких об'єктів і явищ, як вияв філософського принципу їх загального взаємозв'язку, є одним з основних факторів сучасного розвитку науки і техніки. Згідно з цим принципом об’єкт уважається вивченим, якщо він є зрозумілим як деяка неперервна система взаємопов'язаних і взаємодіючих елементів. Загальна теорія систем стверджує, що об'єкт або процес будь-якої природи є системним. Це означає, що системний зміст мають не тільки матеріальні утворення природного або штучного походження, але й різні їх ізоморфні концептуальні моделі, тобто геометричні мисленні образи, локалізовані у свідомості людини.

Ці образи є невід’ємним атрибутом нарисної геометрії, тому що вони слугують «натурою» для їх графічного зображення. Тим самим визначається формально-логічний взаємозв'язок евклідової і нарисної геометрій, який зумовлює інтегральний характер останньої і їі системний зміст.

Системна парадигма теорії оборотних зображень [6] зумовлює системний зміст педагогічної технології навчання нарисної геометрії майбутніх архітекторів, яка складається 3 трьох дидактичних підсистем - чому навчати, як навчати і як навчатися (рис. 1).

Дидактичний зміст першої підсистеми складається 3 двох частин - ідеології i гносеології, друга підсистема присвячується методології системного навчання, третя організації і методичному забезпеченню самоосвіти студентів.

Своєрідністю цієї математичної науки є її синтетичність, або штучність, оскільки вона синтезує проекційні зображення реальних чи уявних об'єктів 3 точок i ліній, підпорядковуючи їх необхідним геометричним зв'язкам i відношенням, графічно моделюючим відповідні зв'язки і відношення між елементами об'єкта, що зображується, як їх системи, що описуються аксіоматикою евклідової геометрії.

Тому штучна нарисна геометрія, що зображає природну евклідову, також повинна мати власну аксіоматику як графічну модель аксіоматики геометрії Евклідового простору, у зв’язку з чим є також природовідповідною і фундаментальною наукою.

Як інтегральна, або комплексна, наука, вона органічно об'єднує раціональне мислення, що засноване на об’єктивному знанні системної природи об’єктів, процесів і явищ 3 їх емоційним сприйняттям, яке збагачується образотворчим змістом. Тому в колі раціональних знань доцільною $є$ світоглядна інформація про системну природу будь-яких об’єктів, психологічні особливості їх чуттєвого, зокрема, зорового сприйняття, і абстрактнологічний зміст їх евклідового пізнання. Така інформація нібито виходить за межі традиційної навчальної програми 3 нарисної геометрії, але, будучи наданою для самостійного вивчення у вигляді творчого повтору інформації з біології, природознавства й евклідової геометрії, яку студенти одержували у школі, вона їм «розплющує очі» до розуміння власне нарисної геометрії й одночасно задовольняє вимогам до гуманітаризації цієї синтетичної математичної науки. 


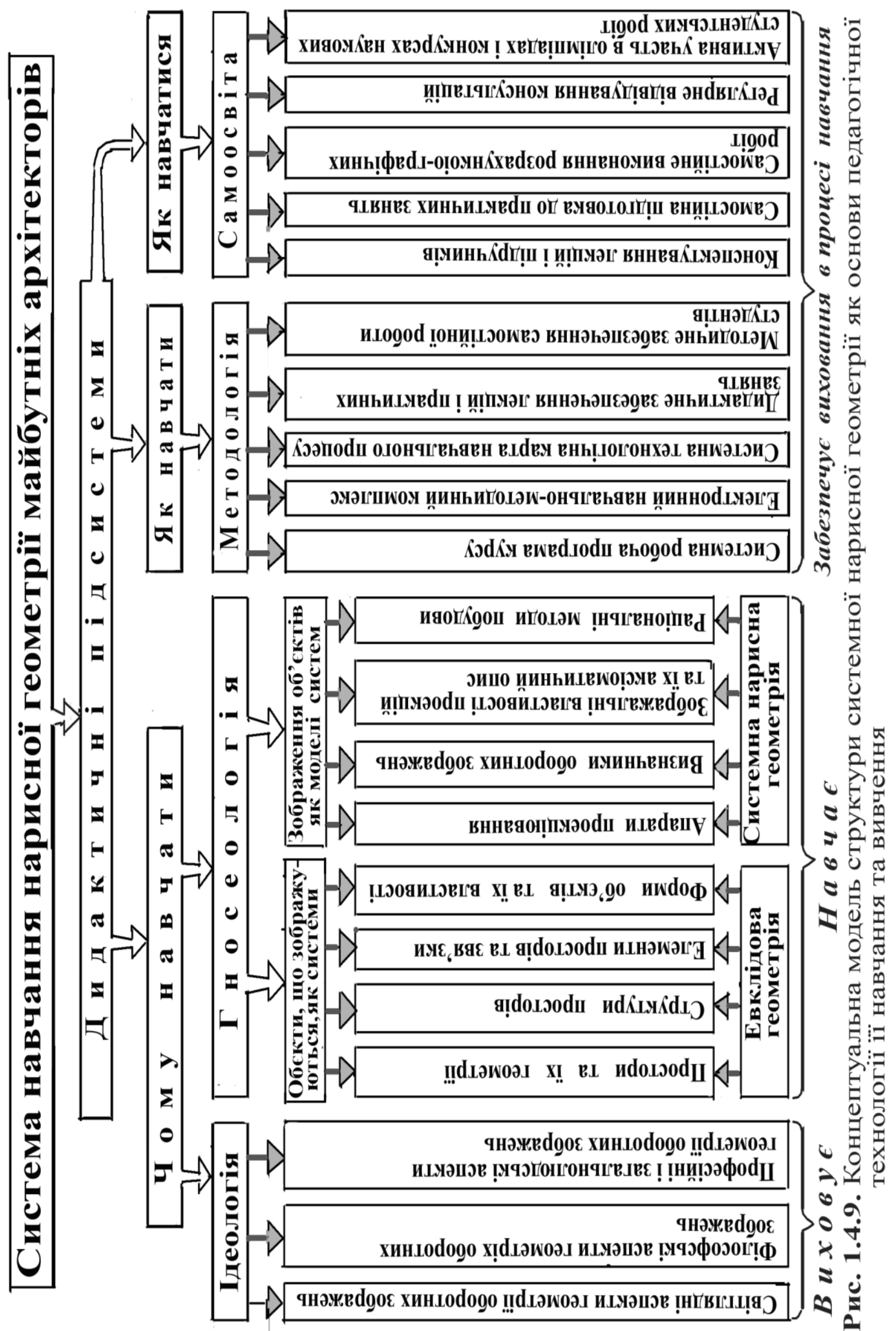

Висновки: 1. Тривале існування загальновизнаного кризового стану довишівської геометро-графічної підготовки учнівської і студентської молоді, яке гальмує й ускладнює засвоєння студентами архітектурних факультетів об'єктивних знань теорії оборотних зображень i практичних умінь їх грамотного виконання, потребують принципового 
перегляду дидактичного змісту іï парадигми як прикладної науки.

2. Прийняття за концептуальну основу зазначеного перегляду парадигми розуміння природи об'єкта як складної системи взаємопов'язаних елементів, а його оборотного зображення - як системи зображень цих елементів, взаємопов'язаних графічними моделями геометричних зв'язків і відношень між ними, сприяє створенню системної нарисної геометрії як фундаментальної синтетичної науки тому, що вона є геометрією картинного простору, яка досліджує зображальні властивості його елементів, які містять інформацію про позиційні і метричні властивості дійсної форми тих об’єктів, що зображені.

3. Дидактичний зміст нарисної геометрії слугує формально-логічною основою створення системної педагогічної технології iï навчання майбутніх архітекторів, ефективність якої зумовлюється іiі інтегральністю, що сприяє створенню діалектичної взаємодії перцептуального й концептуального образів мислення як основи поступового перетворення буденного мислення першокурсників на конструктивно-композиційне як основу проектного.

Якщо наведені аргументи на користь фундаментальності системної нарисної геометрії $\epsilon$ достатньо переконливими, то перспективами іiї подальшого розвитку $\epsilon$ виконання автором таких науково-педагогічних завдань: 1. Успішний захист дисертації «Система навчання нарисної геометрії майбутніх архітекторів» на здобуття наукового ступеня доктора педагогічних наук. 2. Розроблення навчальної програми 3 системної нарисної геометрії як фундаментальної математичної науки, ії узгодження і затвердження в «Інституті інноваційних технологій в освіті» при МОН України. 3. Написання підручника «Системна нарисна геометрія» з грифом МОНУ для геометрографічної підготовки студентів творчих спеціальностей ВНЗ України.

\section{Література}

1. Коменський Ян Амос. Великая дидактика // Я. А. Коменский, Дж. Локк, Ж. Ж. Руссо, И. Г. Пестолоцци. Педагогическое наследие / сост. В. М. Кларин, А. Н. Джуринский. - Москва : Педагогика, 1989. - 416 с. 2. Джеджула О. М. Теорія і методика графічної підготовки студентів інженерних спеціальностей вищих навчальних закладів: дис. ... доктора пед. наук / О. М. Джеджула. - Київ : 2008. - 456 с. 3. Гедзик А. М. Графічна підготовка майбутнього вчителя технологій: [монографія] / А. М. Гедзик. - Умань : Сочінський, 2011. - 306 с. 4. Ковальов Ю. М. Прикладна геометрія : [підручник для ВНЗ] / Ю. М. Ковальов, В. М. Верещага. - Київ : ДІЯ, 2012. - 427 с. 5. Михайленко В. Є. Нарисна геометрія / В. Є. Михайленко, М. Ф. Свстіфеєв, С. М. Ковальов, О. В. Кащенко. - Київ : Вища школа, 2004, - 302 с. 6. Ткач Д. И. Системная парадигма теории обратимых изображений / Д. И. Ткач // Теорія та методика навчання математики, фізики, інформатики. - Вип. VIII. Т. 1. - Кривий Ріг: Видавничий відділ НМетАУ, 2010. - С. 131-139.

УДК 378.091.21:39

Ольга Ткаченко

\section{ДЕЯКІ АСПЕКТИ ПРОБЛЕМИ ФОРМУВАННЯ ТВОРЧОЇ ОСОБИСТОСТІ МАЙБУТНЬОГО ВЧИТЕЛЯ ПОЧАТКОВИХ КЛАСІВ У КОНТЕКСТІ КОМПЕТЕНТНІСНОГО ПІДХОДУ}

Ткаченко О. М. Деякі аспекти проблеми формування творчої особистості майбутнього вчителя початкових класів у контексті компетентнісного підходу.

У статті акцентовано увагу на важливості для сучасного фахівця в галузі початкової 